Istanbul University, fatma.ozmen@istanbul.edu.tr, Istanbul-Turkey Cemal Aküzüm

Dicle University, cemalakuzum@hotmail.com, Diyarbakir-Turkey

\author{
http://dx.doi.org/10.12739/NWSA.2013.8.4.1C0598
}

\title{
OKUL ORTAMINDA KÜLTÜREL FARKLILIKLARDAN KAYNAKLANAN ÇATIŞMALAR VE ÇATIŞMA YÖNETIMİ YAKLAŞIMLARI-ALİPAŞA İLKÖĞRETIM OKULU ÖRNEĞİ
}

\section{ÖZET}

Bu araştırma, Diyarbakır il merkezinde yer alan ve birçok farklı kültür ve etnik gruptan gelen öğrencilerin öğrenim gördüğü, Alipaşa İlköğretim Okulu'ndaki kütürel farkılıklardan kaynaklanan çatışmanın varlığı, nedenleri ve yönetme yollarının, öğretmen ve yönetici görüşleri temelinde irdelendiği niteliksel bir çalışmadır. Araştırmada, çalışma grubunu, Alipaşa İlköğretim Okulu'nda görev yapan yöneticiler, sınıf öğretmenleri ve rehber öğretmenler oluşturmuştur. Yarı yapılandırılmış görüşme soruları aracılığı ile çalışma grubunda bulunan 25 eğitimcinin (5 yönetici, 4 rehber öğretmen ve 16 sinıf öğretmeni) görüşme yöntemi aracılığı ile görüşleri alınmıştır. Elde edilen veriler, içerik analizi yöntemiyle, kodlanarak belirlenen temalar altında gruplandırılmış ve yorumlanmıştır. Ulaşılan sonuçlar doğrultusunda, kültürel içerikli çatışmaların daha etkili şekilde yönetilebilmesi için birtakım önerilere yer verilmişir. Okul yöneticisi ve öğretmenlerin çatışmaların yönetimi alanında eğitilmeleri, çevreyle daha sıkı işbirliği sergilemeleri, diğer kurum ve kuruluşlar ile karşılıklı olarak yardımlaşmaları yapılan önerilerden bazılarıdır.

Anahtar Kelimeler: Kültürel Farklılıklar, Çatışma, Çatışma Yönetimi, ̇̇lköğretim Okulları, Okul Yönetimi

\section{MANAGEMENT OF CONFLICTS STEMMED FROM CULTURAL DIFFERENCES IN SCHOOL ENVIRONMENT-THE SAMPLE OF ALIPASHA ELEMENTARY SCHOOL \\ ABSTRACT}

This research, is a qualitative study which aims to examine the presence, reasons, and handling ways of culturally oriented conflicts in Alipaşa elementary school in the city of Diyarbakır to which numerous culturally and ethnically differet students have been attending. In that research, the study group comprised of school managers, classroom teachers and guidance teachers working in Alipaşa elementary school. Through a semi-structured interview questions the views of 25 educators (5 managers, 4 guidance teachres and 16 classroom teachers) were obtained. The obtained data were coded through content analiysis method, and grouped under the themes according to the similiarities and differences of the codes. In the line of the obtained results some recommendations were made related to effective management of culturally oriented conflicts. Ennhancing the tranining of managers and teachers on the management of culturally oriented conflicts, enhancing collaboration among the institutions and the school environment are some of them.

Keywords: Cultural Oriented, Conflicst, Conflict Management, Elementary Schools, School Management 


\section{GIRIŞ (INTRODUCTION)}

Çatışma, kişilerin farklı nitelikleri, beklentileri, amaçları, iletişim şekilleri gibi özellikleri nedeniyle, kaçınılmaz olarak ortaya çıkan, sosyal ve etkileşimci bir olgudur. Çatışmaların ortaya çıkmasında temel faktör, insanlar arasındaki farklılıklar ve uyuşmazlıklardır. Bu farklılıklar, farklı kültürlerden gelen kişiler arasında olabildiği gibi, aynı kültürden gelen kişiler arasında da yaşanabilmektedir (Avruch, 2004). Bununla birlikte, kültürel farklılıklardan kaynaklanan çatışmalar, kişiler üzerinde yarattığı yabancılaşma, uyumsuzluk, düşük performans vb. çok daha yıkıcı etkileri nedeniyle önemle üzerinde durulması gereken bir durum oluşturur (Doerr, 2004:2-3; Lu, Gilmour, Kao ve Huang, 2005:10-11; Ore, 2008).

Eğitim kurumları, farklı kültürlerden gelen birçok kişinin bir arada eğitim gördüğü sosyal alanlardır. Kişilerin sahip oldukları kültürel nitelikleriyle oluşturdukları farklılıklar bazen bir çatışma nedeni oluşturmakta ve bu çatışmalar zamanında teşhis edilemeyip iyi yönetilemediği takdirde, eğitimden beklenen yararın elde edilmesi güçleşmektedir (Doerr, 2004:117; Gümüşeli, 1994:2; Özdevecioğlu ve Çelik, 2009:96).

\section{2. ÇALIŞMANIN ÖNEMI (RESEARCH SIGNIFICANCE)}

Bu araştırmanın genel amacı, Diyarbakır'ın Alipaşa İlköğretim Okulunda görev yapan yönetici ve öğretmenlerin görüşleri temelinde, öğretmenlerin, sınıf yönetiminde karşılaştıkları kütürel farkılıklardan kaynaklanan çatışmaları, öğrenci performansını artırıcı yönde, nasıl yönettiklerini ortaya çıkarmak; ve yapılan önerilere yer vermektir. Bu genel amaç çerçevesinde aşă̆ıdaki sorulara yanıtlar aranmıştır:

- Okuldaki kütürel farkılıklardan kaynaklanan çatışmalara ilişkin mevcut durum nedir?

- Okuldaki kütürel farkılıklardan kaynaklanan çatışmaların nedenleri nedir?

- Kütürel farkılıklardan kaynaklanan çatışmaların öğrenci ve öğretmen üzerindeki etkileri nasıldır?

- Öğretmenler kültürel farklılıklardan kaynaklanan çatışmaları yönetmede hangi çatışma yönetimi yaklaşımlarını sergilemektedirler?

- Kültürel farklılıkların yol açtığı çatışmaları, örgütsel etkililiği artıracak şekilde yönetmek için neler yapılabilir?

okullar, öğrencilerin her bakımdan geliştirilmelerinin amaçlandığı örgütlerdir. Ancak, okullar, çok farklı dinamiklerin rol oynadığı yerlerdir. Farklı kültürel nitelikler gösteren bireyler arasında çeşitıi tür ve şiddette çatışmaların yaşanması olasıdır. kültürel niteliklerden kaynaklanan çatışmaların, bireye ve örgüte zarar vermeyecek, bir arada yaşamanın yollarını zzenginleştirecek şekilde yönetilmesi gerekir.

Bu araştırma, farklı kültürel ortamlardan gelen öğrencilerin yoğun olarak bulunduğu Alipaşa i̇lköğretim okulunda, yaşanan çatışmaların mevcut durumunu, kişiler üzerindeki etkisini ve çözüm yollarını ortaya koyması bakımından önemli görülmektedir. Bu araştırmada ulaşılan sonuçların, diğer okullar için de, konuya önem vermek açısından yarar sağlayacağı umulmaktadır.

\section{TEORIK ARKAPLAN (THEORITICAL BACKGROUND)}

Öğrenilerek uygulamaya dökülen kolektif bir insan davranışı olarak kültür; örf, adet ve geleneklerin, inanç ve kabullerin, 
tavırların edinilerek paylaşıldığı karmaşık bir sistem olarak insan hayatının her aşamasını etkilemektedir (Chacko, 2003:1088). İnsan toplulukları, bireylerin karşılaştığı sorunları çözümlemek ve belirli durumlarda ihtiyaçlarını karşılayabilmek üzere çeşitli araçlara ihtiyaç duymaktadır. Tüm sosyal topluluklarda belirli maddi ihtiyaçları karşılamak amacıyla oluşturulmuş araç ve tekniklerin yanı sıra sosyal ilişkileri düzenleyen kurallar, gelenekler, fikirler ve kişisel düşünceler mevcuttur. İşte bu sosyal ilişki ve sistemlerin toplamı, kültür kavramını meydana getirmektedir. En basitinden en gelişmişine kadar her türlü sosyal toplulukta kültür denilen ortak bir olgunun mevcudiyeti görülmektedir (Köse, Tetik ve Ercan, 2001:220).

İlgili literatür incelendiğinde kültüre ilişkin genel kabul görmüş bir tanımdan söz edebilmek güçtür. Çünkü kültür, farklı disiplinlerde hatta aynı disiplin içinde dahi farklı şekillerde tanımlanmakta ve kullanılmaktadır. Bu çeşitlilik, kültürün birçok sosyal bilimin kesişme noktasında bulunması ve özellikle insan bilimi, sosyoloji, sosyal psikoloji ve örgütsel davranış gibi disiplinlerin kabul ve varsayımlarını yansıtmasından kaynaklanmaktadır (Durğun, 2006: 113; Schein, 1990:110).

Benzer şekilde, bulundukları toplumun ve kültürün özelliklerini taşıyan bireylerden oluşan örgütler de çeşitli ve farklıdırlar (Thompson, 1976:127). Nasıl ki insanlar, kültürleme biçimlerine bağlı olarak farklı kişiliklere sahip iseler, örgütlerin de aynı şekilde sahip oldukları özellikler, sahip oldukları farklı kültürlerle açıklanabilmektedir (Köse ve Ünal, 2000:4). Schein (1984) daha bütüncül bir yaklaşım benimseyerek örgüt kültürünü; bir grubun kendi içinde bütünleşme ve dış çevreyle uyum sorunlarını çözerken yarattığı ve geliştirdiği; yeni üyelerine algılama, düşünme ve hissetme yolu olarak aktardığı varsayımlar ve inançlar bütünü olarak tanımlamıştır. Schein'in bu tanıma dayalı geliştirdiği modelinde kültür üç düzeyden oluşmaktadır: Kültürel paradigmayı oluşturan örgüt üyelerinin temel varsayımları (insana, ilişkilere, gerçeğin doğasına yönelik), bu varsayımlara dayanan değerler, semboller ve uygulamalardır.

Okul örgütünü oluşturan kültür de aslında tek bir kültür olmayıp çeşitli alt kültürler, hatta bazen birbirine karşı kültürler gelişebilmektedir. Okullarla ilgili olarak, yönetim kültürü, öğretmen kültürü, öğrenci kültürü, sınıf kültürü gibi sınıflandırmalar yapılabilir (Şişman ve Turan, 2004:133). Okul ortamında kültürü oluşturan bu dinamiklerin amaç, değer, inanç ve dolayısıyla davranışlarda oluşturduğu farklılıklar çoğu zaman çatışmaları doğuran ana etmenler olmaktadırlar.

Çatışma, tüm toplumlarda yaşanan dinamik bir etkileşimin sonucu ortaya çıkan doğal bir olgudur. Örgütsel ve sosyal yaşamın gereği olan çatışma, bireylerin kendi içlerinde veya diğer bireylerle, grupların kendi içlerinde veya diğer gruplarla olan ilişkilerinde; amaç, duygu, düşünce ve inançlarında uyumsuzlukların olduğu veya zıtııkların yaşandığı her durumda karşımıza çıkan evrensel bir kavramdır (Korkmaz, 1994:77).

Çatışmanın pek çok farklı tanımı bulunmaktadır. Bu tanımlar araştırmacının çatışmayı bir çıktı, bir süreç veya bir iletişim biçimi olarak algılamalarına bağlı olarak farklılıklar göstermektedir (Alexander, 1995:33). En genel anlamda çatışma, anlaşmazlık ve uyuşmazlıklar sonucunda sosyal varlıklar arasında ortaya çıkan interaktif bir süreç olarak tanımlanmaktadır (Sirivun, 2001:7). Çatışma, dahil olan kişi veya kişilerin iç ve dış koşullarıyla şekillenen, bireysel veya grup performansını olumlu veya olumsuz biçimde etkileyen kişiler arası bir dinamiktir (Lin, 2003:17). 


\begin{abstract}
Teknolojinin gelişmesi, ekonominin küreselleşmesi ve hareketliliğin artması ile hem bireysel hem de örgütsel düzeyde farklı kültürlere mensup insan etkileşimi artmaktadır. Bu etkileşim, insanları, kültürel farklılık konusunda daha duyarlı olmasını gerektirirken, daha çok çatışmayı da kaçınılmaz kılmaktadır (Akkirman, 1998:2; Karataş, 2007; Sims, 2002:245; Yu and Chen, 2008:149).
\end{abstract}

\title{
4. KÜLTÜREL ÇATIŞMALAR (CULTURAL CONFLICTS)
}

Kültürel farklılıklardan kaynaklanan çatışmayı, birbiriyle uyuşmayan ilgileri, bakış açıları, geçmişi ve amaçları olduğunu fark eden, birbirine bağlı iki grup arasındaki şiddetli görüş ayrılığı süreci olarak tanımlamak mümkündür (Ting-Toomey ve diğ., 2000:47). Kültürel sınırlarla ayrılmış bireyler ve gruplar arasında meydana gelen çatışma, tanım gereği kütürel farkılıklardan kaynaklanan çatışma olarak sayılabilir. Fakat aynı toplumdaki bireyler de potansiyel olarak farklı kriterlerle, farklı yollarla örgütlenmiş aile, meslek, siyasi parti, dil, inanç, etnik köken gibi birkaç grubun üyesi olabilmekteler. Bu durum, kültürel çatışmaların, birçok farklı düzeyde eşzamanlı olarak kültürel sınırlarda meydana gelebildiğini göstermektedir (Avruch, 2004).

Özellikle temel girdisinde, sürecinde ve çıktısında insan olan okullarda çatışma daha da belirgin olarak ortaya çıkmaktadır. Çünkü okulların toplumsal işlevi nedeniyle öğretmenler, öğrenciler, veliler, yöneticiler ve toplumdaki diğer gruplar içinde ve arasında çatışma için elverişli bir ortam her zaman vardır (Gümüşeli, 1994:2). Şişman'ın (2002) (akt. Kirişçi, 2010) da belirttiği gibi, okullardaki insan ilişkileri, bürokratik kurallardan daha çok ortak değerler etrafında gerçekleşmektedir. Çünkü okul, değer üreten, değerlere göre işleyen ve belirli değerleri gerçekleştirmeye çalışan bir örgüttür. Okulda çeşitli değerlerin bir arada bulunması ve birbiriyle çatışması ise okulun örgüt özelliklerinden birisidir (s.2).

Aynı topluluğa ait bireyler arasında, aynı sınıfa mensup olma durumu çatışmanın yoğunluğunu azaltır. Çünkü farklı kültürlerin çatışmasıyla karşılaştırıldığında, daha fazla karşılıklı bağımlılık yaşar ve sık iletişim halinde olurlar. Bununla birlikte kültürel farklılıklar, sadece çok uluslu veya dış ilişkileri olan örgütlerde değil tüm örgütlerde aktif rol oynar (Yalçın ve Keleş, 2004). Çalışanların kültürel değerlerini bilmek aynı zamanda onların çatışma yaşadıklarında verecekleri tepkileri öngörebilmeyi de sağlamaktadır. Çalışanların çatışma yaşama biçimleri bireylerin içinde bulundukları toplumun kültürel değerleri ile biçimlenmektedir. Bu biçimlendirme süreci, birey toplum içinde henüz sosyalleşme süreci içinde iken başlamakta ve ömrünün sonuna kadar sürmektedir. Çalışanlarının çatışma yaşama biçimlerini bilen bir yönetim kadrosu, çatışma yaşandığında onu fırsata dönüştürme şansına sahip olabilecektir ve bu sayede birçok örgütün korkulu rüyası olan çatışma durumunu çok daha sağlıklı bir biçimde geçirebilecektir (Yalçın ve Erçen, 2004:202).

Çatışmalar, bazen olumlu bazen de olumsuz etkilere neden olabilmektedir (Gibson, Ivancevich ve Donnelly, 2000:225). Bu açıdan, çatışmayla etkili şekilde başa çıkabilme yeteneği, çatışmaları etkin bir şekilde yönetebilme ile yakından ilişkili olup yönetici ve öğretmenlerin kesin olarak sahip olması gereken önemli bir beceri olarak değerlendirilmektedir (De Cenzo, 1997:401). Çatışmaların yönetilmesi, geniş tanımıyla çatışmanın var olduğunun benimsenmesi ve örgüt amaçlarının gerçekleştirilmesinde bu çatışmaların birer araç olarak kullanılmasıdır. Yani kısaca çatışma, bir problem olarak değil çözümün bir parçası olarak düşünülmelidir. Çünkü problemlerin çözümü için bilgi ve düşünce farklılığı zorunludur (Tjosvold, 1991:3). 
Çatışma Yönetimi Stratejileri, çatışma durumlarında bireylerin belirli davranış modelleri doğrultusunda kendilerini ifade etme eğilimleridir (Gümüşeli, 1994:22).

Örgütsel çatışmaların yönetimi alan yazında oldukça çok yer tutmaktadır. Çatışma yönetimine ilişkin yaklaşımlar örgüt yönetimi kuramlarından etkilenmiş olup, her bir kurama göre çatışmaların yönetimi de farklılaşmaktadır (Gümüşeli, 1994:22; Özmen, 1997:44-45). Rahim (1992) (akt. Özmen, 1997) çatışma yönetimi tarzlarını Blake ve Mouton'ın geliştirdiği çatışma yönetimi tarzlarına dayanarak geliştirmiş ve kişilerin kendi çıkarları veya karşı tarafın çıkarları çerçevesinde beş grupta ayırarak incelemektedir (ss.42-45). Bu yaklaşımlar:

- Bütünleşme (İşbirliği-Problem Çözme): Birey, kendi ihtiyaçları kadar diğerlerinin ihtiyaçları üzerinde de yoğunlaşarak, problemleri yeni ve yaratıcı çözümler üreterek çözmeye çalışır. $\mathrm{Bu}$ strateji her iki taraf açısından kabul edilebilecek bir çözüme ulaşmak için sorunu çözmeye odaklaşır. Her iki tarafın da kazandığı yapıcı bir çatışma yönetimi tarzıdır (Gross ve Guerrero, 2000:206).

- Kaçınma: Tarafların hem kendi hem de karşı tarafın ilgi ve ihtiyaçlarına verdikleri önemin düşük olduğu durumlarda başvurulan bir tarzdır. Bu tarz davadan vazgeçme, sorumluluğu başkasına yükleme ya da kenara çekilme davranışları ile kendini gösterir (Cornille, Pestle ve Walker, 1999:69).

- Uzlaşma (Karşılıklı Ödün Verme): Çatışan tarafların karşılıklı olarak bazı isteklerinden vazgeçmesi durumudur. Taraflar hem kendileri için hem de karşı taraf için orta düzeyde kaygı duyarlar (Rahim, 1992, akt. Özmen, 1997:46). Bu stratejide kazanan ya da kaybeden yoktur (Can, 1994:298).

- Ödün Verme: Çatışan taraflardan birinin, kendi çıkarlarından vazgeçip, karşı tarafı hoşnut etmeye dayanan bir çatışma yönetimi tarzıdır. Tek taraflı karar verme sürecine neden olur. Bu strateji, karşı tarafın isteklerini kabul etmekte, kendini daha az güçlü hisseden insanlar tarafından uygulanır (Gross ve Guerrero, 2000:205; Uğurlu, 2001:43).

- Hükmetme (Üstünlük Kurma-Rekabet): Taraflardan birinin karşı tarafın çıkarlarını dikkate almadan, kendi çıkarlarını ön plana alarak çatışmayı çözmeye çalışmasıdır. Bir tarafın kazandığı, diğer tarafın kaybettiği bir çatışma yönetimi tarzı olarak, geride husumet, çözümsüzlük bırakır. Genellikle hükmeden taraf yetki ve gücünü kullanır, ancak bu yaklaşım çatışmaları yok etmez, sadece erteler (Gümüşeli, 1994:93; Robbins, 1974:72).

\section{YÖNTEM (METHOD)}

\subsection{Araştırma Deseni (Research Design)}

Bu araştırma, sosyal olguları bağlı bulundukları çevre içerisinde araştırmayı ve anlamayı ön plana alan nitel araştırma yaklaşımı çerçevesinde tasarlanmıştır. Nitel araştırma yaklaşımı, araştırmacının esnek olmasını, toplanan verilere göre araştırma sürecini yeniden biçimlendirmesini ve gerek araştırma desenini gerekse toplanan verilerin analizinde tümevarıma dayalı bir yaklaşım izlemesini gerektirmektedir (Yıldırım ve Şimşek, 2006:40). Bu çerçevede, okul yöneticilerinin ve öğretmenlerin kültürel farklılıklardan kaynaklanan çatışmalara yönelik görüş ve önerileri betimlenmeye çalışılmıştır. 


\section{2. Çalışma Grubu (Work group)}

Çalışma grubunu, Diyarbakır İi merkezinde bulunan Alipaşa İlköğretim Okulunda görev yapan 5 okul yöneticisi, 16 sınıf öğretmeni ve 4 rehber öğretmen olmak üzere toplam 25 kişi oluşturmaktadır. Araştırmada bu okulun seçilme nedeni, okuldaki öğrencilerin çok farklı etnik gruplardan gelmesidir.

\subsection{Veri Toplama Aracl (Data Collection Instrument)}

Çalışmada, kütürel farkılıklardan kaynaklanan çatışma konusuna yönelik alanyazın taranmış ve konu ile ilgili hususlar belirlenmiştir. Bu kapsamda görüşme yapılan kişilere beş soru yöneltilmiştir. Görüşmede yer alan sorular, alanyazın eşliğinde ve uzman görüşlerine başvurularak belirlenmiştir. Bu sorular aşağıda yer almaktadır:

- Okulunuzda kültürel farklılıklardan kaynaklanan çatışmalar meydana gelmekte midir?

- Bu çatışmaların olası nedenlerine ilişkin, önemli gördüğünüz beş hususu belirtir misiniz?

- Bu çatışmalar kişiler üzerinde nasıl bir etki yaratmaktadır? Öğrenci açısından beş hususu; öğretmen açısından beş hususu açıklar mısınız?

- Kültürel farklılık kaynaklı yıkıcı çatışmaların yaşanmasını önlemek için önerileriniz nelerdir?

- Bu çatışmaları, öğrenci ve öğretmen performansını artıracak yönde, olumlu bir biçimde yönetebilmek için neler yapılabilir?

Belirlenen sorular çalışma grubunda bulunan 25 görüşmecinin tamamına, yüz yüze görüşme sürecinde sorulmuş, alınan yanıtlar, araştırmacılar tarafından yazılarak kaydedilmiştir.

\subsection{Verilerin Analizi (Analysis of the Data)}

Görüşme yapılan kişilere yöneltilen sorulara alınan yanıtlar, çatışmanın türü, sebebi, kişiler üzerindeki bıraktığı etkileri ve çözüm yolları çerçevesinde, içerik analizine tabi tutulmuştur. Alanlazın bilgisi de dikkate alınarak, önemli görülen kavramlar, anlamlarına göre kodlanarak, benzerlikler ve farklılıklar çerçevesinde temalar oluşturulmuş ve bu temalar eşliğinde yanıtlar yorumlanmıştır.

Araştırmanın güvenirliğini sağlamak için, araştırmada ulaşılan kodlar ve bu kodların söz konusu temaları temsil edip etmediği durumu, uzman görüşüne sunulmuş, gerekli düzenlemeler yapılarak son şekli verilmiştir. Verilerin çözümlenmesinde, araştırmacıya esneklik sağlaması, gerekli düzenlemeleri izin vermesi açısından, bilgisayar ortaminda nitel veri analizi (NVivo 8) paket programından yararlanılmıştır.

\section{BULGULAR VE YORUMU (FINDINGS AND INTERPRETATIONS)}

$\mathrm{Bu}$ bölümde, okul yöneticilerinin, sınıf öğretmenlerinin ve rehber öğretmenlerin görüşleri, belirlenen temalar eşliğinde, modeller biçiminde gösterilerek, yorumlanmıştır.

6.1. Bulgular ve Yorumu (Findings and Intrepretation)

6.1.1. Kültürel kaynaklı çatışmalara ilişkin mevcut durum (The current situation of culturally oriented conflicts)

Okulda kültürel farklılıktan kaynaklanan çatışmaların mevcut durumuna ilişkin, görüşler, yüzde ve frekans değerleriyle verilmiştir (Tablo 1). 
Tablo 1. Kültürel kaynaklı çatışmaların mevcut durumuna ilişkin görüşlerin dağılımı

(Table 1. The Distribution of the views related the current situation of culturally oriented conflicts)

$\begin{aligned} & \text { Okulunuzda kültürel farklılıklardan kaynaklanan çatışmalar } \\
& \text { meydana gelmekte midir? }\end{aligned}$
\begin{tabular}{|c|c|c|c|c|c|}
\hline Gruplar ve Yüzdeleri & \multicolumn{2}{c|}{ Yanıtlar ve Yüzdeleri } \\
\hline Gruplar & $\mathrm{N}$ & $\frac{\circ}{\circ}$ & Evet & $\frac{\circ}{\circ}$ & Hayır \\
\hline Okul yöneticisi & 5 & 20 & 5 & 100 & 0 \\
\hline Sınıf öğretmeni & 16 & 64 & 16 & 100 & 0 \\
\hline Rehber öğretmen & 4 & 16 & 4 & 100 & 0 \\
\hline Toplam & 25 & 100 & 25 & 100 & 0 \\
\hline
\end{tabular}

Araştırmaya katılan 5 okul yöneticisi (20), 16 sınıf öğretmeni $(\% 64)$ ve 4 rehber öğretmenin (\%16) tamamı (\%100), okulda kültürel farklılıklardan kaynaklanan çatışmalar yaşandığını belirterek, çatışmanın varlığı konusunda görüş birliği sergilemişlerdir (Tablo 1). Çalışma grubunun bu yanıtı, görev yaptıkları okulda kültürel farklılıktan kaynaklanan çatışmalara ilişkin yapılan bu çalışmanın gerekliliğini de ortaya koymaktadır. Eğitim örgütünün personel açısından temel çatısını oluşturan okul idaresinin, rehberlik servisinin ve öğretim etkinliğinin uygulaycıları olan ve araştırmaya katılan öğretmenlerin tamamının "evet" yanıtını vermesi konunun önemini yansıtmaktadır.

\subsubsection{Kültür Kaynaklı Çatışmaların Nedenleri (Reasons for Culturally Oriented Conflicts)}

Okulda öğrenci-öğrenci ve öğrenci-öğretmen arasında yaşanan kültür kaynaklı çatışmaların nedenlerine ilişkin yönetici, sınıf öğretmeni ve rehber öğretmenlerin görüşleri, belirlenen temalar eşliğinde aşağıda verilmiştir (şekil 1). Şekil üzerindeki rakamlar, çatışmanın nedenlerine ilişkin görüşlerin alt temalardaki dağılımını göstermektedir.

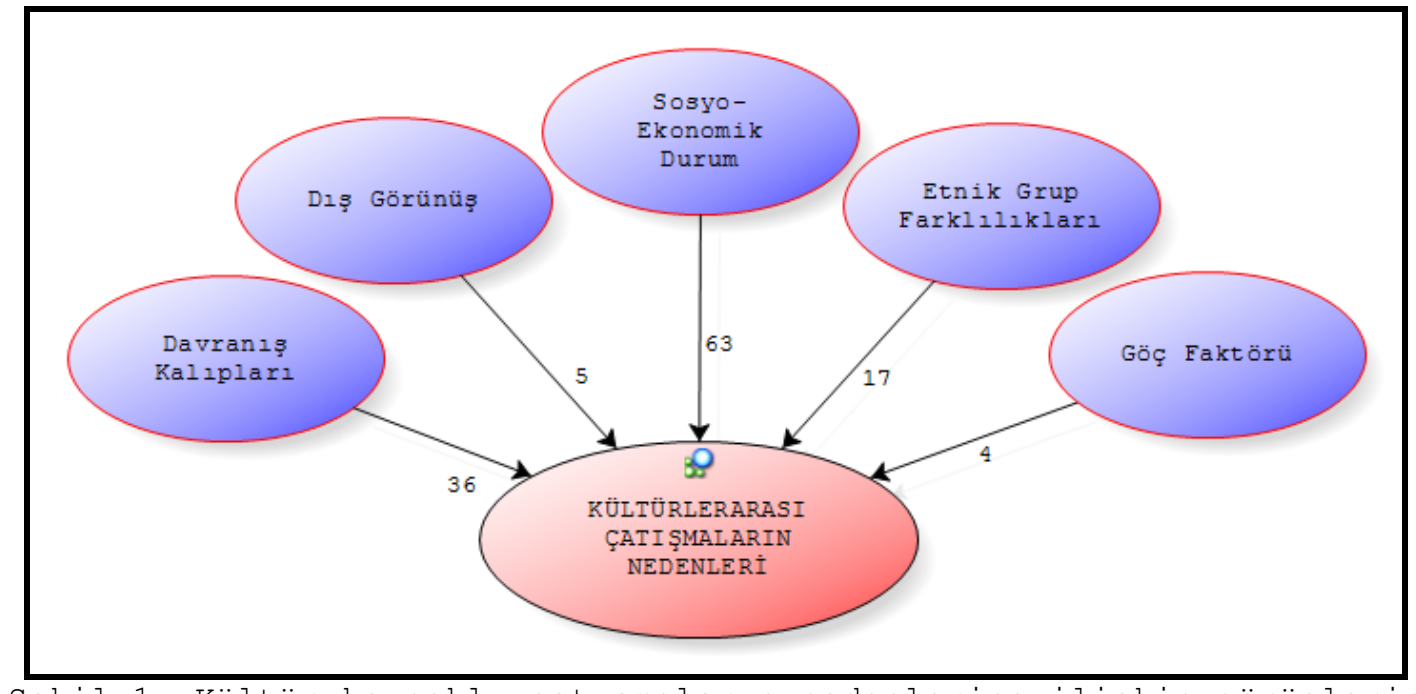

Şekil 1. Kültür kaynaklı çatışmaların nedenlerine ilişkin görüşlerin dağılımı

(Figure 1. Distribution of the views towards the reesaons of culturally oriented conflicts)

Kişelerin sahip oldukları kültürün yol açığı çatışmaların önemli nedenleri olarak "sosyo-ekonomik durum", 50,4 (f:63) oranında dile 
getirilmiş olup, en yüksek oranda belirtilen ve ailevi, çevresel, ekonomik ve eğitimsel etkenleri kapsayan çatışma nedeni olarak görülmektedir (Şekil 1). "Davranış kalıpları" kaynaklı çatışma nedeni ise, (f:36, \%28,8) yaklaşık 29 oranında işaret edilmekte olup, öğrencinin veya öğretmenin ailesinden, yaşadığı çevreden edindiği dolayısıyla mensubu olduğu kültürden getirmiş olduğu gelenek ve göreneklerle şekillenen davranış yapısını kapsamaktadır. "Etnik grup farklılıkları" (f:17, 13,6) yaklaşık o14 oranında dile getirilmiştir. Bu durum, öğretmenin veya öğrencinin dil, din ve etnik köken farklılıklarından kaynaklanan çatışmaların nedenlerini yansıtmaktadır. "Dış görünüş" (f:5, 4) ve göç faktörü (f:4, 3,2) nispeten azalan oranlarda ve birbirine yakın değerlerle dile getirilen çatışma nedenleri olup, diğer faktörlere göre daha az oranda belirtilen etkenler arasında yer almaktadırlar. Bu konuda okul yöneticilerinin ve öğretmenlerin görüşmedeki ifadelerinden bazıları, belirlenen temalar dahilinde aşağıda yer almaktadır:

- Davranış Kalıpları: "Kültürün temel öğeleri olan gelenek ve göreneklerden kaynaklanan davranış farklılıkları hem öğrencilerin kendi aralarında hem de öğretmenleriyle zaman zaman uyuşmazlıklara neden olmaktadır" (Rehber öğretmen-1).

- Dış Görünüş: "Okulumuzdaki öğrencilerin kültürel anlamdaki farklılıkları birbirilerinin dış görünüşünü değerlendirme noktasında da farklılığa neden olmaktadır. Özellikle ten rengi ve kıyafet ayırımcılığı konusu dikkate değer çatışma nedenleri oluşturmaktadır" (Öğretmen-1)

- Sosyo-Ekonomik Durum (Çevresel Faktörler): "Öğrencinin ve ailesinin yetiştiği ortamdaki insanların yaşam tarzının ve kültürel farklılıklara ilişkin bakış açllarının bireyleri etkilemesi. Olumlu veya olumsuz anlamdaki bu etkilerle okula gelen öğrencilerin iletişimi de oldukça sancılı olmaktadır" (Öğretmen-9).

- Sosyo-Ekonomik Durum (Ekonomik Faktörler): "Yakın çevrenin dolayısıyla ailelerin ekonomik açıdan eşit durumda olmaması ailede ve okulda sosyo-ekonomik gerginlik diye adlandırılabilecek bir ortamı da beraberinde getirmektedir" (Rehber öğretmen-2).

- Sosyo-Ekonomik Durum (Eğitimsel Faktörler): "Sosyal ve kültürel anlamda karmaşık ve geri kalmış bir okul çevresi, yürütülen öğretimsel faaliyetleri derinden etkilemektedir. Bu karmaşık ve geri kalmış yapı, bireysel anlamda temel ihtiyaçları karşılamaya odaklandığından eğitim hizmetini geri plana itmektedir" (Rehber öğretmen-3) .

- Sosyo-Ekonomik Durum (Ailevi Nedenler): "Ailedeki çocuk sayısının çok olması bireysel anlamda çocuğa olan ilginin azalmasına neden olmaktadır. Ayrıca ailenin kendi kültürü dışındaki kültürlere ilişkin bilgi sahibi olmaması çocuğu sosyal anlamda daha dar kalıplarda düşünmeye sevk etmektedir. Bu gibi nedenler öğrenciler arasında veya öğrenci-öğretmen arasında çatışmayı kaçınılmaz kılmaktadır" (Öğretmen-4).

- Etnik Grup Farklılığı (Etnik Grup Üyesi Olma): "Kültürel farklılığımızın ana kaynă̆ı olan etnik grup farklılığı daha çok okul çevresinde yerleşik konumda bulunan ve fazla temsilcisi olmayan etnik bir gruba yönelik önyargılı yaklaşım tarzının neden olduğu bir çatışma durumu mevcuttur" (Öğretmen-2).

- Etnik Grup Farklılığı (Dil Farklılığı): "Dilsel anlamdaki çatışmalarımızın kaynă̆ı genelde öğrenci ve öğretmenlerimizin anadillerinin farklı olmasından kaynaklanmadır". (Yönetici-1). 
- Etnik Grup Farklılığı (Dinsel Faktörler): "Mensubu olunan din veya aynı dininin içindeki mezhep farklılığı uygulama biçimini de farklı kılmaktadır. Biçimsel yaklaşım, dini simgeleyen eylemlerde kendini göstermektedir. Toplumun da bu simgelere yaklaşım tarzının negatif olması hoşgörüsüzlüğü beraberinde getirmektedir" (Öğretmen-4).

- Göç Faktörü: "Kırsal kesimlerden şehre olan göçlerde yakın çevremizin bir uğrak yeri olması kozmopolit bir yapı oluşturmuştur. Bu durum, öğrenciler arasında adaptasyon sorunlarına neden olduğu gibi, uyum sürecinde zaman zaman köy ve kent kültürü çatışması şeklinde kendini göstermektedir" (Öğretmen-15).

\subsubsection{Kültürel Kaynaklı Çatışmaların Kişiler Üzerindeki Etkileri (The Effects of Culturally Oriented Conflicts on Teachers and Students)}

Okulda yaşanan kültürel farklılıklardan kaynaklanan çatışmaların hem öğrenci hem de öğretmenler üzerindeki etkileri aşağıda yer almaktadır (Şekil 2).

Çatışmaların kişiler üzerindeki etkilerine bakıldığında bu etkilerin daha çok öğrenciler üzerinde olduğu görülebilir. Çatışmaların öğrenci üzerindeki en önemli etkileri, "olumsuz davranış eğilimi" (uyumsuzluk, saygısızlık, kin besleme, alay etme, öğretmene karşı düşmanlık ve umursamazlık vb.) (f:27, 25), "iletişimsizlik" (f:24, 22.2); "başarı düzeyinde azalma" (f:19, \%17.6) ve "etnik üstünlük algısı" (kendi kültürünü üstün görme, kültürel kutuplaşma, karşı kültürü görmezlik vb.) (f:13, o12) oranlarında dile getirilmektedir. Diğerleri giderek azalan bir oranda görülmektedir.

Çatışmaların öğretmenler üzerindeki en önemli etkileri ise, "öğretimsel güçlükler" (öğretimin verimsizleşmesi, yöntem seçiminde güçlükler, amaçlarda sapma, sınıf iklimi yaratamama, öğrenme ortamı oluşturamama) (f:22, 24.2); "çevreyle uyumsuzluk" (f:19, ⒛9); "olumsuz tutum geliştirme" (öğrenci ve ailesini olduğu gibi kabullenememe, şiddet eğilimi gösterme, öğrenci ve çevresine önyargılı tutum geliştirme) (f:19,o20.9 ve "motivasyon düşüklüğü" (f:18, \%19.8) olup, diğerleri giderek azalan bir oranda görülmektedir. 


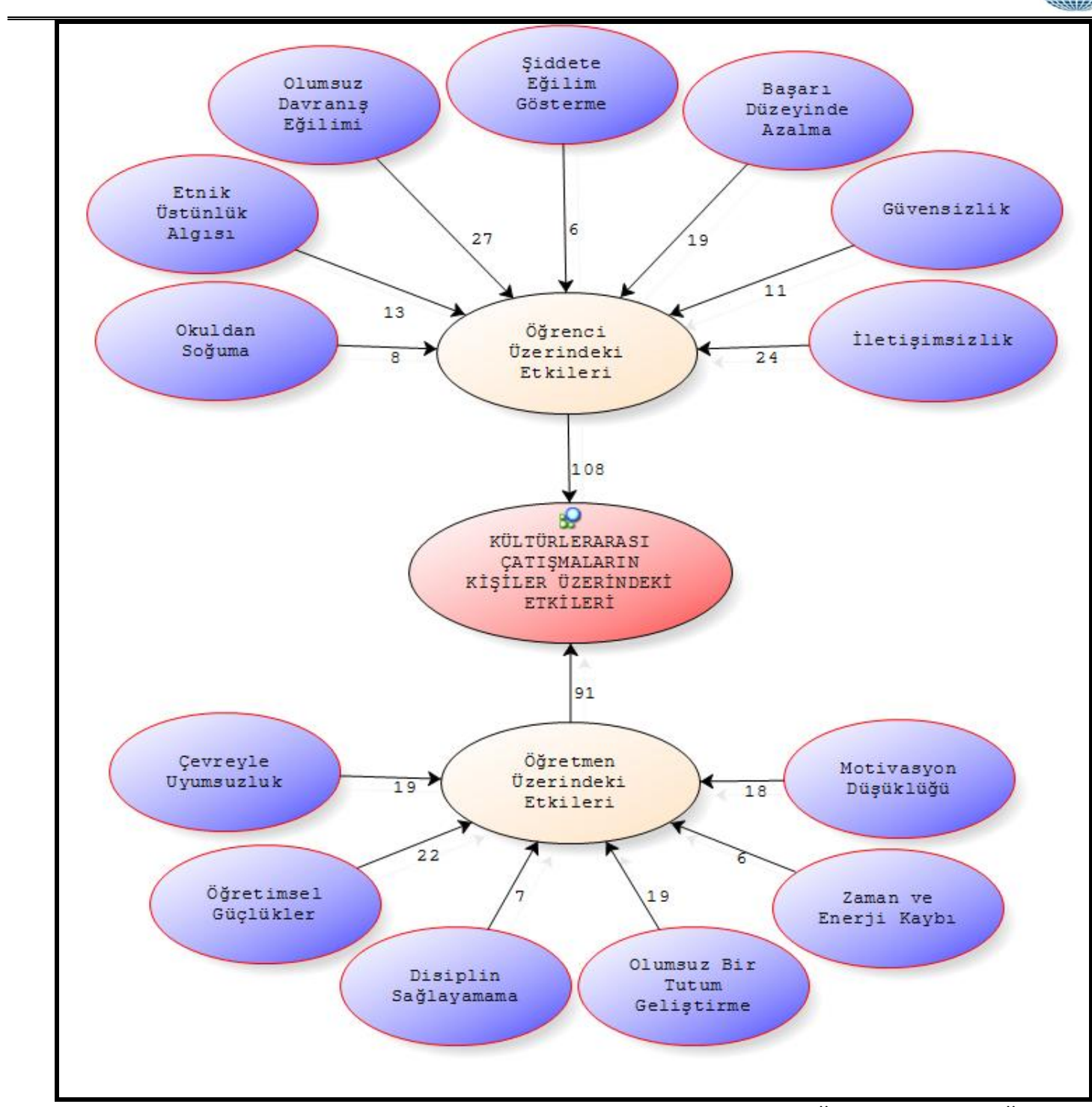

Şekil 2. Kültürel farklılık kaynaklı çatışmaların Öğretmen ve Öğrenci Üzerindeki Etkilerine İlişkin Görüşlerin Dağılımı

(Figure 2.Distribution of the views towards the effects of culturally oriented conflicts on teachers and students)

Bu konuda okul yöneticilerinin ve öğretmenlerin ifade ettikleri çatışmanın etkileri, onların kendi sözcükleriyle aşağıda yer almaktadır:

- Çatışmaların öğrenci üzerindeki etkilerine yönelik katılımcıların görüşleri aşağıda yer almaktadır:

- Okuldan Soğuma: "Sürekli aşağılanma, uyum problemi yaşama gibi sorunlar öğrenciyi asıl amaçlarından alıkoymaktadır. Okulu kendisi için bir çatışma ortamı olarak algılayan öğrencinin okuldan uzaklaşarak yakın çevresine sığınması olası bir durumdur" (Öğretmen-2).

- Etnik Üstünlük Algısı: "Belirli etnik gruplara dair sahip olunan önyargllar, özellikle aileler tarafindan desteklendiğinden, karşı tarafa yönelik bir aşağılama eğilimi söz konusu olmakta ve öğrencilerin üyesi oldukları etnik grupları üstün tutma, kendi dışındakileri yadsıma durumu söz konusu olabilmektedir" (Öğretmen-1). 
- Olumsuz Davranış Eğilimi: "Çatışma sonrası, öğrencinin değişen dünyada temel değerlere gerekli önemi vermeyen, çevresine karşı umursamaz ve uyumsuz birey olarak yetişmesi söz konusu olmaktadır" (Öğretmen-7).

- Şiddete Eğilim Gösterme: "Bu tür çatışmalar, öğrencilerin birbirlerine fiziksel şiddet uygulamalarına ve çevrelerine zarar vermekten kaçınmamalarına neden olmaktadır" (Öğretmen4).

- Başarı Düzeyinde Azalma: "Çatışma ortamının varıı̆̆ını hisseden veya çatışma ortamında olan öğrenci, enerjisini başka alanlara kanalize ettiğinden derse odaklanamama, yeteneklerini sergileyememe dolayısıyla eğitim anlamında istenilen düzeyde başarıyı elde edememesine neden olmaktadır" (Rehber öğretmen-4).

- Güvensizlik: "Çatışmada özellikle mağdur edilen taraf yani öğrenci, öğretmenine ve arkadaşına güven duymayan bir kişilik geliştirmekte aynı zamanda dış dünyayı da güvensiz bir yer olarak algılamaktadır" (Rehber öğretmen-4).

- İletişimsizlik: "Kültürel anlamda bir çatışma, aynı zamanda bir yanlış anlama ve iletişim probleminin de göstergesidir. Çatışmanın en olumsuz yanlarından biri, sonrasında öğrencilerde yaşanılan içine kapanıklık ve iletişim kuramama problemleridir" (Öğretmen-11).

- Çatışmaların öğretmen üzerindeki etkilerine ilişkin katılımcıların görüşlerindan bazıları aşağıdaki gibidir:

- Çevreyle Uyumsuzluk: "Öğretmenler, öğrencilerin kültürel farklılıklarına ilişkin çatışmaları çözmek için uğraşırken aileler devreye girerek öğretmene olumsuz tutumlar takınmaktalar. Bu da öğretmen ile okul çevresi arasında uyuşmazlıkları kaçınılmaz kılmaktadır" (Öğretmen-6) .

- Öğretimsel Güçlükler: "Bir kültür öğesi olan dil farklılıklarından dolayı bazı öğrencilerin anlatılan konuları anlayamaması, anlatılan konudan sapmaya neden olmakta dolayısıyla derste ulaşılmak istenen hedefleri zorlaştırmakta bu da öğretmenin öğretme sürecinde zorlanmasına neden olmaktadır" (Öğretmen-1).

- Disiplin Sağlayamama: "Kültürel farklılık kaynaklı çatışmalardan dolayı öğrenciler arasında meydana gelen uyum problemleri, öğretmenin sınıf disiplinini sağlamasını zorlaştırmaktadır" (Öğretmen-1).

- Olumsuz Tutum Geliştirme: "Kültürel farklılıktan kaynaklanan çatışma durumu, kontrolü ve aşılması güç bir olay olduğundan öğretmen, taraf olması durumunda zaman zaman problemi çözümlemeye çalışırken öğrenciye ve ailesine karşı yanıı tutumlar sergileyebilir. Bu da çözümü zorlaştrran en önemli etmendir" (Öğretmen-11).

- Zaman ve Enerji Kaybı: "Öğretmen, enerjisinin ve zamanının çoğunu kültürel kaynaklı çatışmalara ve öğrencilerin edinmiş olduğu davranış bozuklularına ayırdığından, öğretmenin efor kaybına neden olmaktadır" (Öğretmen-7).

- Motivasyon Düşüklüğü: "Kültürel farklılıklardan dolayı meydana gelen çatışmalarda, öğrenci-öğrenci veya öğrenciöğretmen arasındaki uyuşmazlıklara bă̆lı olarak oluşan eğitim-öğretim güçlüğü ve öğrenme süreci yetersizlikleri öğretmenin motivasyon düzeyinin düşmesine sebep olmaktadır" (Öğretmen-6). 


\subsubsection{Kültürel farklılık Kaynaklı Yıkıcı Çatışmalar Yaşanmasını Önlemek İçin Öneriler (Recommendations for the Prevention of Culturally Oriented Destructive Conflicts)}

Görüşmeye katılan denek gruplarının kültürel farklılık kaynaklı çatışmaların önlenebilmesi için denek gruplarının ileri sürdükleri öneriler aşağıda verilmektedir (Şekil 3):

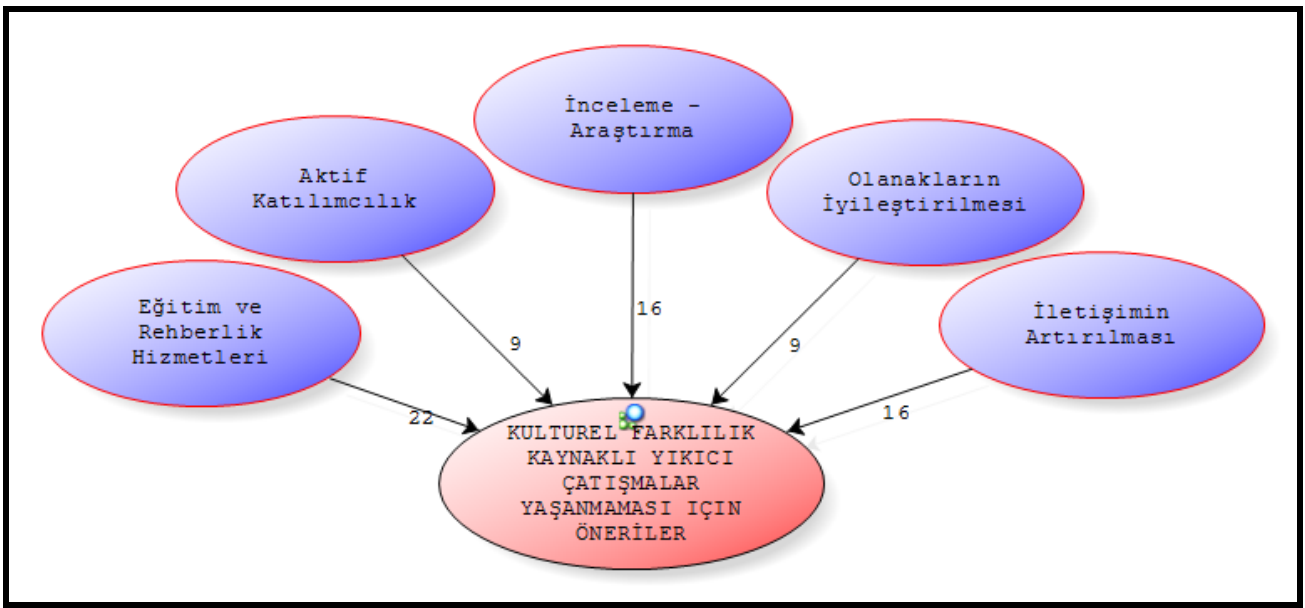

Şekil 3. Kültürel farklılık kaynaklı yıkıcı çatışmaların önlenmesine yönelik önerilere ilişkin görüşlerin dağılımı

(Figure 3. Disitribution of the views related to the recommendations for the prevention of destructive cultural conflicts)

Yönetici ve öğretmen görüşlerine bakıldığında, 22 (f:22, \%30.6) önerinin en çok "eğitim ve rehberlik hizmetleri" alanında çalışmaların yapılmasına yöneliktir. Ayrıca "inceleme-araştırma" ve "iletişimin artırılması" hususları (f:16, 22.2), 16 görüşle ikinci sırada bildirilen öneridir. "Aktif katılımcllık" ve "olanakların iyileştirilmesi" önerileri de eşit oranlarda, (f:9, \%12.5) önerilmiştir. Deneklerin, hem öğrencilerin hem de öğretmenlerin aktif katılabilecekleri faaliyetlere, ön araştırmalara ve eğitime önem verilmesi gerektiğini düşündükleri; okuldan, aileden veya çevreden kaynaklanabilecek olumsuzlukların da giderilmesi için olanakların iyileştirilmesi hususlarına değindikleri görülmektedir. Yönetici ve öğretmenlerin çatışmaların önlenmesi hususunda alınabilecek tedbirlere ilişkin önerilerinden bazıları, belirlenen temalar başlığı altında, aşağıda verilmektedir:

- Eğitim ve Rehberlik Hizmetleri: "Öğretmen ve öğrencilerin performanslarını artırmak için, her kültürün önemli olduğunun öğretmen ve öğrencilere, çevreye uyum seminerleri ile öğretilmesi gerekmektedir" (Yönetici-5).

- Aktif Katılımcılık: "Kültürel farklılıklar göz önünde bulundurularak sınıf içerisinde herkesin kendine uygun roller seçmesi să̆lanmalı dolayısıyla öğrenme sürecine tüm öğrencilerin aktif bir şekilde katılmaları să̆lanmalıdır" (Rehber öğretmen2) .

- Inceleme-Araştırma: "Etnik farklılıkların çok olduğu toplukların kültürel açıdan daha zengin oldukları gezi, gözlem, araştırma ve çeşitli tiyatro oyunlarlyla anlatilabilir. Böylece farklılıkların uyum sürecine daha esnek bir geçiş sağlanabilir" (Öğretmen-2). 
- Olanakların İyileştirilmesi: "Maddi imkanların ve eğitimin yoksunluğu bu tür çatışmaları tetiklediği için bu konularda iyileştirme politikaları geliştirilebilir" (Öğretmen-6) .

- Iletişimin Artırılması: "Öğretmen-veli-öğrenci iletişiminin güçlenmesini sağlayıcı okul içi ve okul dışı kültürel etkinliklere yer verilebilir" (Öğretmen-1).

\subsubsection{Kültürel Farklılık Kaynaklı Çatışmaları Yönetme Yaklaşımları (Approaches for the Management of Different Cultural Oriented Conflicts)}

okul yöneticisi ve öğretmenlerin okulda öğrenci-öğrenci ve öğrenci-öğretmen arasında yaşanan kültürel farklılık kaynaklı çatışmaları çözümleyebilmek ve bu çatışlamaları yönetebilmek için çatışma yönetimi yaklaşımları konusundaki görüşlerine ait bilgiler aşağıda yer almaktadır (Şekil 4).

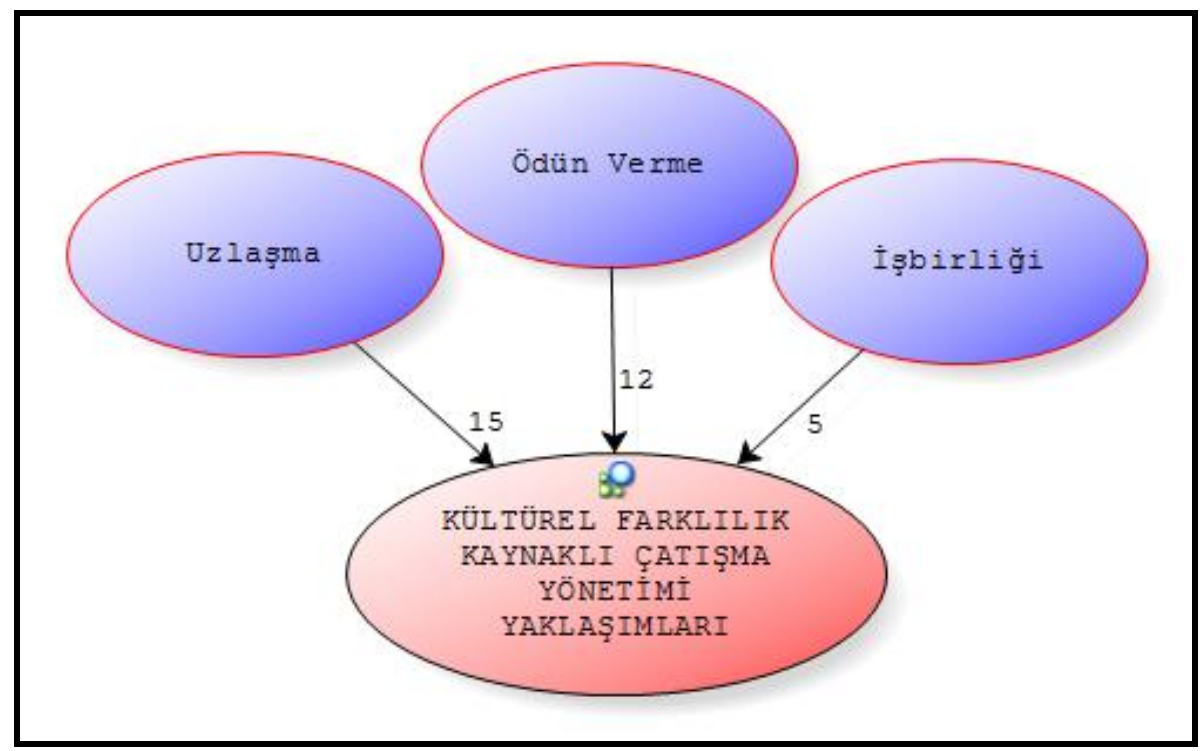

Şekil 4. Kültürel farkllık kaynaklı çatışmaları yönetme yaklaşımlarına ilişkin görüşlerin dağılımı

(Figure 4. Distribution of the views related to the management approaches towards culturally oriented conflicts)

Görüşme yapılan denek gruplarının okulda yaşamış oldukları çatışmaların yönetimi konusundaki yaklaşımlarının, görüşme formunun analizi doğrulrultusunda üç yaklaşımda birleştiği görülmektedir. Bu yaklaşımlar; "uzlaşma yaklaşımı" (f:15, 46.9), "ödün verme yaklaşımı" (f:12, 37.5), ve "işbirliği yaklaşımı" (f:5, ⒖6). Bu üç çatışma yönetimi yaklaşımı çerçevesinde gerek yöneticilerin gerekse öğretmenlerin görüşleri doğrultusunda elde edilen verilere bakıldığında daha çok yapıcı ve çatışma durumunu ortadan kaldırıcı yöntemlerin benimsendiği görülebilir. Ancak denek gruplarının öğrenciöğrenci ve öğrenci-öğretmen arasında yaşanan veya yaşamış oldukları çatışmaların yönetimine ilişkin yaklaşımlarının yukarıda saydığımız üç yaklaşım dışında "hükmetme (üstünlük kurma)", "kaçınma" ve "uyma (itaat etme)" gibi diğer çatışma yönetimi yaklaşımlarına da başvurdukları görülebilir. Çatışma yönetimi konusunda okul yöneticilerinin ve öğretmenlerin ifade ettikleri görüşlerinden bazıları aşağıda yer almaktadır:

- Uzlaşma: "Sınıf içerisinde herkesin eşit olduğu, herkese aynı dersin aynı şartlar altında anlatıldığı vurgulanarak farklılıkların hiçbirine ne bir üstünlük săgladı̆̆ı ne de bir 
eksiklik yarattı̆̆ı ve grupların birbirinin farklılıklarını kabul etmesi öğretilmelidir" (Yönetici-3).

- Ödün Verme: "Çatışmanın önlenmesini sağlayabilmek için öğretmen, kültürel farklılıkların nedenlerinin çok önemli olmadığını belirtirken taraflardan birinin çıkarlarından biraz da olsa vazgeçmesi çok fazla bir kayıp olmayacă̆ı konusuna yoğunlaşmalıdır. Ayrıca hem biz hem de yöneticiler "biz bir aileyiz" sloganıyla çatışmayı azaltmayı amaçlamalıyız" (Rehber öğretmen-4) .

- İ̧̧irliği: Kültürel farklılık içinde oldukları düşünülen grupların empati kurabilmeleri ve daha etkin iletişim kurabilmelerini sağlamak için tarafların yardımını gerektiren etkinlikler ve uygun paylaşım alanları oluşturulmalıdır (Öğretmen-14).

\section{SONUÇ, TARTIŞMA VE ÖNERILER (CONCLUSION, DISCUSSION AND SUGGESTIONS)}

Bireylerin birbirinden farklı etnik gruplara, farklı dil ve dini inançları dolayısıyla farklı kültürlere sahip olmaları, buna paralel olarak bireysel davranışlarının da farklılık göstermesi olağan bir durumdur. Herkes gerek iş yaşantısında, gerekse özel yaşantısında diğer bireylerden farklı beklentilerde bulunmakta, farklı amaçlar gütmektedir. Dolayısıla ortaya çıkan farklılıklar kimi zaman anlaşmazlık, uyuşmazlık vb. durum veya olaylara neden olmaktadır. Karşılaşılan çeşitli durum ve olaylar bireylerin içinde bulundukları ortamlarda çatışma yaşanmasında etkili olmaktadır. Eğitim örgütleri de bireylerin yoğun olarak bulunduğu ortamlardan biri olması nedeniyle sıklıkla çatışma yaşanan yerler olmaktadır.

Bu çalışmada, teorik bölümlerin ardından yer verilen araştırma bulguları bölümünde yer alan analiz sonuçları, görüşmelerin yapıldığı okulda kültürel farklılıklardan kaynaklanan çatışmalarla ilgili mevcut durumun değerlendirilmesine ve öneriler geliştirilmesine yardımcı olmuştur.

Bu araştırmada, ilköğretim okul yöneticileri ve öğretmenleriyle kültürel farklılıklardan kaynaklanan çatışmalar konusunda yapılan görüşmelerde ulaşılan sonuçlar şu şekilde özetlenebilir. Araştırma yapılan okulda görüşme yapılan tüm kişiler, öğrenci-öğrenci arasında olduğu kadar öğrenci-öğretmen arasında da kültürel farklılıklardan kaynakıanan çatışmalar yaşandığını ifade etmişlerdir. Bu durum, araştırma konusu edilen okulda kültürel farklılıklardan kaynaklanan çatışmalarla ilgili bir araştırmanın yapılmasını hem gerekli hem de zorunlu kılmaktadır (Tablo 1 ).

Denek gruplarının kültürel farklılıklardan kaynaklanan çatışmaların nedenleri konusunda ileri sürdükleri görüşleri 5 alt temada toplanmıştır. Bunlar içinde en çok; "sosyo-ekonomik durum", "davranış kalıpları" ve "etnik grup farklılıkları" ön plana çıkmaktadır. Diğer temalar olan göç faktörü ve dış görünüş az oranda dile getirilen nedenlerdendir. Bu hususla ilgili verilen örnek ifadelere de bakıldığında sosyo-ekonomik durum alt başlığı; ailenin genel durumu, çevresel, ekonomik ve öğretimsel faktörleri de kapsadığı görülebilir. Farklı kültürel çevrelerden gelme farklı davranış kalıplarını sergilemeyi kaçınılmaz kıldığından denek gruplarının bu husustaki görüşlerinin oranın yüksek olduğu görülmektedir. Okul çevresinde yerleşik durumda bulunan ve farklı etnik kökenden gelen öğrencilerler arasındaki kültürel farklılıklardan kaynaklanan çatışmalar da üzerinde durulan bir diğer çatışma nedeni olmuştur (Şekil 1). 


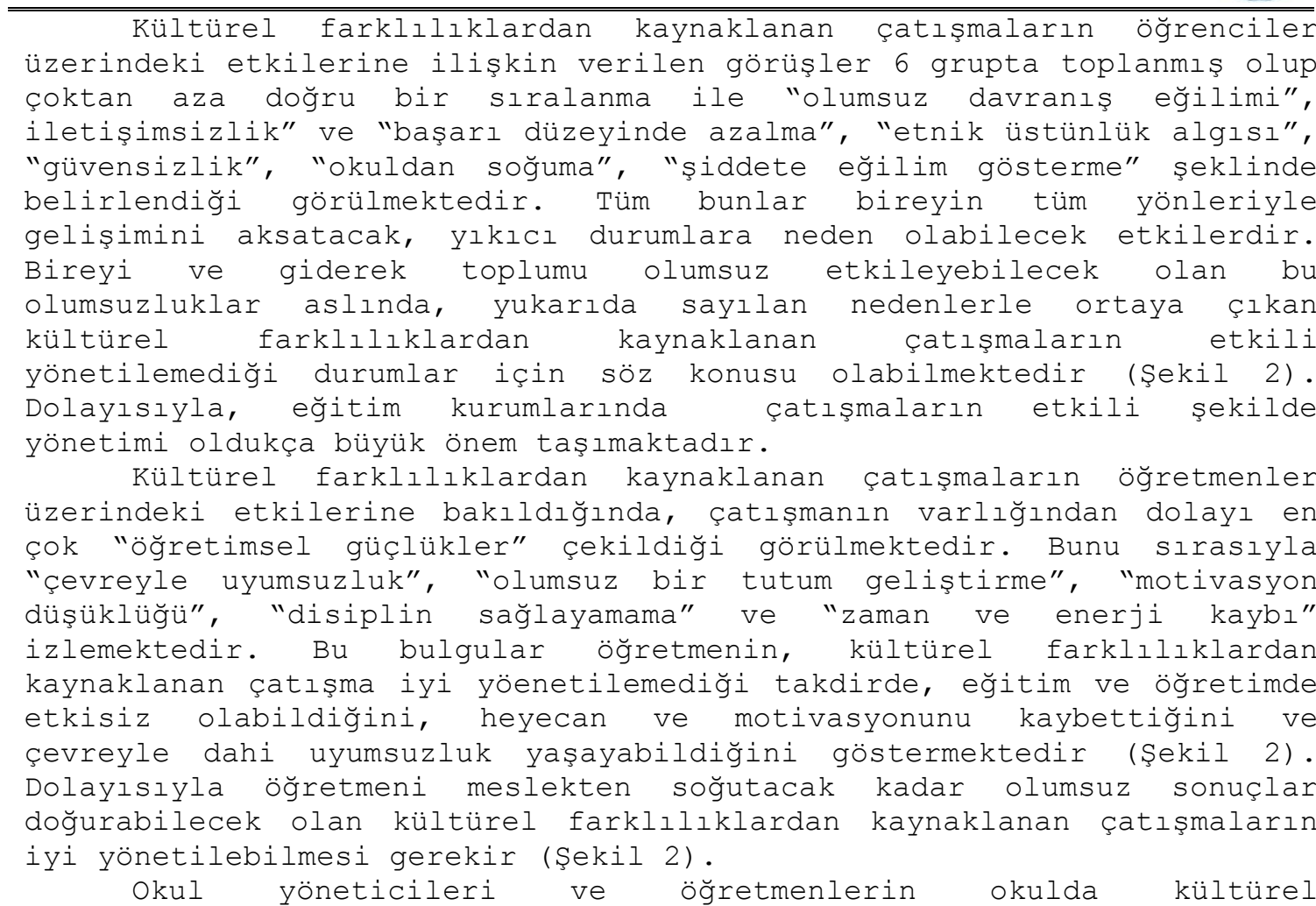
farklılıklardan kaynaklanan çatışmaların en aza indirilmesi ve yıkıcı etkilerinin ortadan kaldırılabilmesi için, alınabilecek tedbirlere ilişkin önerileri ise, 5 alt grupta toplanmıştır. Çatışmaları önlemede ailelerin-öğretmenlerin ve öğrencilerin öncelikle uyum sorunlarını çözümlemek açısından "eğitim ve rehberlik hizmetlerine" ağırlık verilmesi gerektiği vurgulanmıştır. Catışmaya sebebiyet verebilecek tarafların birbirlerini, farklılıklarını tanımlayabilmeleri açısından "inceleme-araştırma" yapılması, "iletişimin artırılması", "aktif katılımcılık" ve "olanakların iyileştirilmesi" hususları önerilmiştir (Şekil 3).

Denek gruplarının kültürel farklılıklardan kaynaklanan çatışmaların yaşanması durumunda bu çatışmaları yönetebilmeye ilişkin görüşlerine bakıldığında, çatışma yönetimi yaklaşımlarının "uzlaşma", "ödün verme" ve "işbirliği" altında yoğunlaştığı, bu durumun ise, çatışma yönetiminde olumlu sonuçlar alınabilecek yönetme tarzlarının benimsendiği şeklinde yorumlanmaktadır (Şekil 4). Ancak yaşamış oldukları veya çeşitli sebeplerle müdahil oldukları çatışmalarda bu yaklaşımların dışında "hükmetme (üstünlük kurma)", "kaçınma" ve uyma (itaat etme)" gibi diğer çatışma yönetimi yaklaşımlarına da başvurdukları görülmektedir (Örnek olaylar).

Araştırmadan elde edilen sonuçlar, alanyazında kültürel farklılıkları konu edinen araştırmalardan elde edilen bulgularla örtüşmektedir. Söz konusu araştırmaların sonuçlarına bakıldığında; Gülbaşı ve Mazlum (2010), toplumları oluşturan farklı etnik ve mezhepsel inanç sistemine mensup toplumsal sınıflar arasında zaman zaman gerilimler ve çatışmaya dönüşen şiddet durumlarının yaşandığını; Yeşil (2007), özellikle kültürel farklılıkların grup içerisinde bütünleşme ve iletişim problemlerinin yaşanmasına ve çatışmalara neden olabileceğini; Gültekin ve Ulukan (2012), yaşanan çatışmaların en temel sebebinin iletişim olduğunu; Triandis (2000) de, kültürel farklılıkların sıklıkla iletişim problemlerine neden olduğunu savunmaktadır. Early ve Gibson (1998) farklı kültürlerin bir arada 
bulundukları durumlarda çatışmaların ortaya çıkma olasılığının yüksek olduğunu ifade ederken, yine bu bağlamda Adler (1986) farklı kültürlerden oluşan gruplarda karar alma, beklentiler, bilginin uygunluğu ve buna benzer konularda anlaşmazlıkların çıkacağını ifade etmiştir. Asunakutlu ve Safran'nın (2004) çalışmalarının sonuçlarına göre, kültürel farklılaşmadan kaynaklanan çatışmalarda en etkili faktör dildir. Çalışanların farklı dili konuşmaları, kendilerini ifade etmekte güçlük çekmelerine yol açmakta ve bu durum yanlış anlama ve anlaşmazlıklara neden olmaktadır. Bu sonuç, yapılan pek çok araştırmadan elde edilen bulgularla örtüşmektedir. Çatışmada etkili olan diğer faktörlerin pek çoğu, din kavramı içerisinde değerlendirilebilecek hususlardır. Alakavuklar ve Arbak (2009) çalışmalarında, dinin çatışmanın önemli bir kaynağı olması yanında değerler, yönetim biçimini de etkilemekte ve bireylerin çatışmayı ele alış biçimlerini belirlediği vurgusunu yapmaktadırlar. Ayrıca, Özmen (1997) çalışmasında, örgütsel çatışmalar ve yönetimi alanında yapılan araştırmaların, diğer birçok ülkede olduğu gibi, Türkiye'de de örgütlerde tüm kademelerde çoğunlukla "işbirliği" ve "uzlaşma" yaklaşımlarının egemen olduğunu, "ödün verme", "kaçınma" ve "hükmetme" yaklaşımlarına başvurma sıklığının ise, çatışan tarafların konumlarına ve güç ilişkilerine göre değişiklik gösterdiğini vurgulamaktadır (s.182).

Elde edilen bu sonuçlardan yola çıkarak şu önerilere yer verilebilir:

- Toplumun geleceğine yön veren önemli örgütlerden okul sistemleri dil, din ve gelenekler bakımından farklı alt kültürleri içinde barındırabildiğinden, kültürel farklılıklardan kaynaklanan çatışmaların yaşanması kaçınılmazdır. Bu bakımdan, okul yönetimi ve öğretenlerin, kültürel farklılıklardan kaynaklanan çatışmaların farkında olmaları; ve bu çatışmaların etkili yönetimi için kendilerini geliştirmeleri gekerir.

- Çatışmaların büyük çoğunluğu iletişim kaynaklı olduğu için farklılık hissedilen alanlarda, bu farklılığa neden olan grupların çeşitli açılardan birbirlerini tanıyıp benimseyebilecekleri ve aktif katılabilecekleri etkinlikler düzenlenebilir.

- Çatışmaların hem öğretmen hem de öğrenciler üzerinde olumsuz etki bırakmasını önlemek amacıyla aile, öğretmen, rehberlik servisi ve öğrenci arasında koordinasyonu sağlayacak sürekliliği olan görüşmeler yapılabilir.

- Başta okul yöneticileri ve öğretmenler olmak üzere, okul personelinin, kültürel farklılıklardan kaynaklanan çatışmaların yönetimi alanında hizmet içi eğitimlerle yetiştirilmeleri, bu çatışmaların iyi yönetilemediği takdirde, kişi ve örgüt üzerinde yaratacağı olumsuz ve yıkıcı etkilerini azaltmada önemli rol oynayacaktır.

- Kültürel farklılıklardan kaynaklanan çatışmaları doğuran nedenler, mensubu olunan toplumdan, aile kurumundan, çevreden başlayarak öğrenci ve öğretmenler aracılığıyla okula taşındığından, çatışmaların nedenleri iyi analiz edilmeli ve bunları yapıcı ve bütünleştirici yönde çözümleyebilmek için okul çapında politikalar geliştirilmelidir. Bu bağlamda, okul bölgesindeki diğer kurum ve kuruluşlarla işbirliği içinde düzenlenecek, sempozyumlar, konferanslar, festivaller, fuarlar, panayırlar gibi geniş kapsamlı etkinlikler, farklı kültürlerin bir birini daha iyi tanıması, kabul etmesi ve uyum sağlaması bakımlarından yararlı sonuçlar doğurabilecektir. 


\section{KAYNAKLAR (REFERENCES)}

- Adler, N.J., (1986). International Dimensions of Organisational Behaviour (2nd ed.). Belmont, California: PWS-Kent Publishing Company.

- Akkirman, A.D., (1998). Etkin Çatışma Yönetimi ve Müdahale

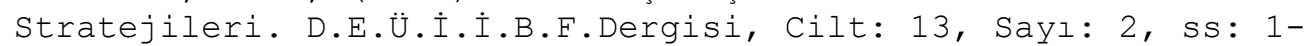
11 .

- Alakavuklar, O.N. ve Arbak, Y., (2009). Kişisel Değerlerin Kişilerarası Çatışma Yönetim Biçimleri Üzerindeki Etkisi. 17. Ulusal Yönetim ve Organizasyon Kongresi. Eskişehir: Eskişehir Osmangazi Üniversitesi, Bildiriler Kitabı, ss: 52-57.

- Alexander, D.C., (1995). Conflict Management Styles of Administrators in Schools for the Deaf: Teacher Perceptions of Job Satisfaction. Yayımlanmamış Yüksek Lisans Tezi. Washington: Gallaudet University.

- Asunakutlu, T. ve Safran, B., (2004). Kültürel Farklılıklardan Kaynaklanan Çatışmalara Yönelik Bir Araştırma (Marmaris Turizm Sektörü Örneği). Dokuz Eylül Üniversitesi Sosyal Bilimler Enstitüsü Dergisi, Cilt: 6, Sayl: 1, ss: 26-38.

- Avruch, K., (2004). Cross-Cultural Conflict, in Conflict Resolution. İçinde Hipel, K.W. (Ed.), In Encyclopedia of Life Support Systems (EOLSS), Developed Under the Auspices of the UNESCO. Oxford, UK: Eolss Publishers, http://www.eolss.net / $25 / 11 / 2012$.

- Can, H., (1994). Organizasyon ve Yönetim. Ankara: Siyasal Kitapevi.

- Chacko, E., (2003). Culture and Therapy: Complementary Strategies for the Treatment of Type-2 Diabetes in An Urban Setting in Kerala. Social Science \& Medicine, Volume: 56, Number: 5, pp: 1087-1098.

- Cornille, T.A., Pestle, R., and Walker, R., (1999). Teachers' Conflict Management Styles With Peers and Students' Parents. The International Journal of Conflict Management, Volume: 10, Number: 1, pp: 69-79.

- De Cenzo, D.A., (1997). Human Relations Personel and Professional Development. New Jersey: Prentice Hall.

- Doerr, J.C., (2004). Dealing with Cross-Cultural Conflict in A Multicultural Organisation: An Education Management Perspective. Unpublished Master Thesis. Unisa: University of South Afric.

- Durğun, S., (2006). Örgüt Kültürü ve Örgütsel İletişim. Yüzüncü Yıl Üniversitesi Eğitim Fakültesi Dergisi, Cilt:3, Sayı:2, ss: 112-132.

- Earley, P.C. and Gibson, C.B., (1998). Taking Stock in Our Progress on Individualism-Collectivism: 100 Years of Solidarity and Community. Journal of Management, Volume: 24, Number:3, ss: 265- 304 .

- Gibson J.L., Ivancevich, J.M., and Donnelly, J.H., (2000). Organizations: Behavior Structure Processes (10th ed.). Boston: Irwin McGraw-Hill.

- Gross, M.A. and Guerrero, L.K., (2000). Managing Conflict Appropriately and Effectively: An Application of the Competence Model to Rahim's Organizational Conflict Styles. The International Journal of Conflict Management, Volume: 11, Number: 3, pp: 200-226. 
- Gülbaşı, H. ve Mazlum, A., (2010). Çatışma Odağında Alevi-Sünni İli̧̧kileri ve "Öteki" Algısı. Uluslararası İsan Bilimleri Dergisi, Cilt: 7, Sayı: 2, ss: 320-345.

- Gültekin, Z. ve Ulukan, C., (2012). Çokuluslu Ekiplerde Kültürel Farklılıklar ve Yönetimi. Anadolu Üniversitesi Sosyal Bilimler Dergisi, Cilt: 12, Sayl: 1, ss: 89-102.

- Gümüşeli, A.亡̇., (1994). İzmir İli Ortaöğretim Okulları Yöneticilerinin Çatışmayı Yönetme Biçimleri. Yayımlanmamış Doktora Tezi. Ankara: Ankara Üniversitesi.

- Karataş, S., (2007). Afyonkarahisar İli Merkez İlköğretim Okullarında Görev Yapan Sınıf ve Branş Öğretmenlerinin Kurum İçi Çatışmaları Yönetim Biçemine İlişkin Görüşleri. Bilim Eğitim Düşünce Dergisi, Cilt: 7, Sayı:2. http://www.universitetoplum.org/text.php3?id=321 / 12/05/2013.

- Kirişçi, A., (2010). Öğretmenlerin Kültürel Değerleri ve Çatışma Yaklaşımları. Yayımlanmamış Yüksek Lisans Tezi. İstanbul: Yıldız Teknik Üniversitesi.

- Korkmaz, M., (1994). Örgütlerde Çatışmalar ve Nedenleri. Yayımlanmamış Doktora Tezi. Ankara: Gazi Üniversitesi.

- Köse, S. ve Ünal, A., (2000). Türk Yönetim Kültürü Tarihi Açısından Çağdaş Türk İşletmelerinde Yönetim Değerleri. 8. Ulusal Yönetim ve Organizasyon Kongresi Bildiriler. Nevşehir: Erciyes Üniversitesi, 15- 27 Mayıs.

- Köse, S., Tetik, S. ve Ercan, C., (2001). Örgüt Kültürünü Oluşturan Faktörler. Celal Bayar Üniversitesi Yönetim ve Ekonomi Dergisi, Cilt: 7, Sayı: 1, ss: 219-242.

- Lin, S., (2003). Relationships among Conflict Management Styles, Employees' Job Satisfaction and Team Effectiveness- A Comparison between Public and Private Hospitals in Taiwan. Unpublished Doctoral Thesis. ABD: Nova Southeastern University.

- Lu, L., Gilmour, R., Kao, S.F., and Huang, M.T., (2005). A Cross-Cultural Study of Work/Family Demands, Work/Family Conflict and Wellbeing: The Taiwanese vs British. Career Development International, Volume: 11, Number: 1, pp: 9-27.

- Ore, L.E., (2008). Cross-Cultural Conflict Management Skills as Competency for A Diverse Workforce. ORASI Consulting Group, Inc.

- Özdevecioğlu, M. ve Çelik, C., (2009). Örgüt Kültürü Tipleri Ittbariyle Bireylerin Algıladıkları Mağduriyet Farklılıklarını Belirlemeye Yönelik Bir Araştırma. Atatürk Üniversitesi İktisadi ve İdari Bilimler Dergisi, Cilt: 23, Sayı: 1, ss: 95-112.

- Özmen, F., (1997). Fırat ve İnönü Üniversitelerinde Örgütsel Çatışmalar ve Çatışma Yönetimi Yaklaşımları. Yayımlanmamış Doktora Tezi. Elazığ: Fırat Üniversitesi.

- Robbins, P.S., (1994). Örgütsel Davranışın Temelleri. (Çev. Öztürk, S.A.). Eskişehir: Etam A.Ş. Basım ve Yayım.

- Schein, E.H., (1984). Coming to A New Awareness af Organizational Culture. Sloan Management Review, Volume: 25, Number: 2, pp: 1-17.

- Schein, E.H., (1990). Organizational Culture. American Psychologist Published, Volume: 45, Number: 2, pp: 109-119.

- Sims, R.R., (2002). Managing Organizational Behavior. London: Westport, Connecticut Quorum Books.

- Sirivun, U., (2001). An İnvestigation of the Primary and Secondary Conflict Management Style Preferences of Men and Women in the Role of Local Managers, International Managers and 
College Students In Thailand. Unpublished Doctoral Thesis. ABD: Nova Southeastern University.

- Şişman, M. ve Turan, S., (2004). Eğitim ve Okul Yönetimi. İçinde Özden, Y. (Ed.). Eğitim ve Okul Yöneticiliği El Kitabı. (ss.99145). Ankara: Pegem A Yayıncılık.

- Thompson, D.J., (1976). Örgütler Çalışırken Yönetim Teorisinin Toplum Bilimsel Temeli. (Çev. Sözen, U. ve Üçok, T.). Ankara: Kalite Matbaası.

- Ting-Toomey, S., Yee-Jung, K.K., Shapiro, R.B., Garcia, W., Wright, T.J., and Oetzel, J.G., (2000). Ethnic/Cultural Identity Salience and Conflict Styles in Four US Ethnic Groups.

International Journal of Intercultural Relations, Volume: 24, Number: 1, pp: 47-81.

- Tjosvold, D., (1991). The Conflict-Positive Organization: Stimulate Diversity And Create Unity. New York: Addison-Wesley Pub. Co.

- Triandis, H.C., (1995). Individualism and Collectivism. Boulder: Westview Press, CO.

- Uğurlu, F., (2001). İlköğretim Okulu Müdürlerinin Çatışma Yönetme Sitilleri. Yayımlanmamış Yüksek Lisans Tezi. İzmir: Dokuz Eylül Üniversitesi.

- Yalçın, A. ve Erçen, E.Y., (2004). Kültür ile şekillenen Çatışma Tepkileri Üzerine Bir Uygulama. Çukurova Üniversitesi Sosyal Bilimler Enstitüsü Dergisi,cilt: 13, sayı: 2, ss: 201-217.

- Yalçın, M. ve Keleş, G.N., (2004). Eğitim Örgütlerinde Çatışma ve Yönetimi (Dersödevi).

http://www.altsayfa.com/siyaset/dosyalar/282-catisma-kulturiliskisi / 27/06/2013.

- Yeşil, S., (2007). Uluslararası Ortaklıklar: Kültürel Farklılıklar ve Bu Farklılıkların Üst Yönetim Grubunun Çalışma Ve Performansına Etkileri. Kocaeli Üniversitesi Sosyal Bilimler Enstitüsü Dergisi, Sayı:13 2007/1, ss: 232-246.

- Yıldırım, A. ve Şimşek, H., (2006). Sosyal Bilimlerde Nitel Araştırma Yöntemleri. Ankara: Seçkin Yayıncılık.

- Yu, T. and Chen, G.-M., (2008). Intercultural Sensitivity and Conflict Management Styles in Cross-Cultural Organizational Situations. Intercultural Communication Studies, Volume: 17, Number: 2, pp: 149-161. 